\title{
THE POWER OF GIVING: CHINA
DEEPENS INVOLVEMENT IN
REFUGEE AFFAIRS
Song Lili
}

A

T THE BEGINNING OF 2018, there were 68.5 million displaced people worldwide, including 25.4 million refugees - the highest number in the sixty-eight-year history of the Office of the United Nations High Commissioner for Refugees (UNHCR). In June 2018, the UN published the final draft of the Global Compact on Refugees - a follow-up on the New York Declaration for Refugees and Migrants that was unanimously adopted by 193 states at the UN Leaders' Summit for Refugees and Migrants in 2016. The UN General Assembly adopted the Global Compact on 17 December 2018, the US and Hungary being the only states having voted against it.

In August 2018, the US reduced its contribution to the United Nations Relief and Works Agency for Pales- tine Refugees in the Near East - the UN agency mandated to support the five million Palestinian refugees in the Middle East - by eighty per cent. The US is the largest donor and most influential actor in the international refugee protection regime, but, under President Trump, it has reduced its commitments to helping refugees generally; in September, Trump announced that he would cap the refugee intake in 2019 at 30,000, down from 110,000 when he took office.

As in other areas where the US is in retreat, China has stepped forward. China's involvement in the international refugee protection system increased notably in 2018. China acceded to the 1951 Refugee Convention and the 1967 Refugee Protocol in 1982. But it has long been perceived mainly 


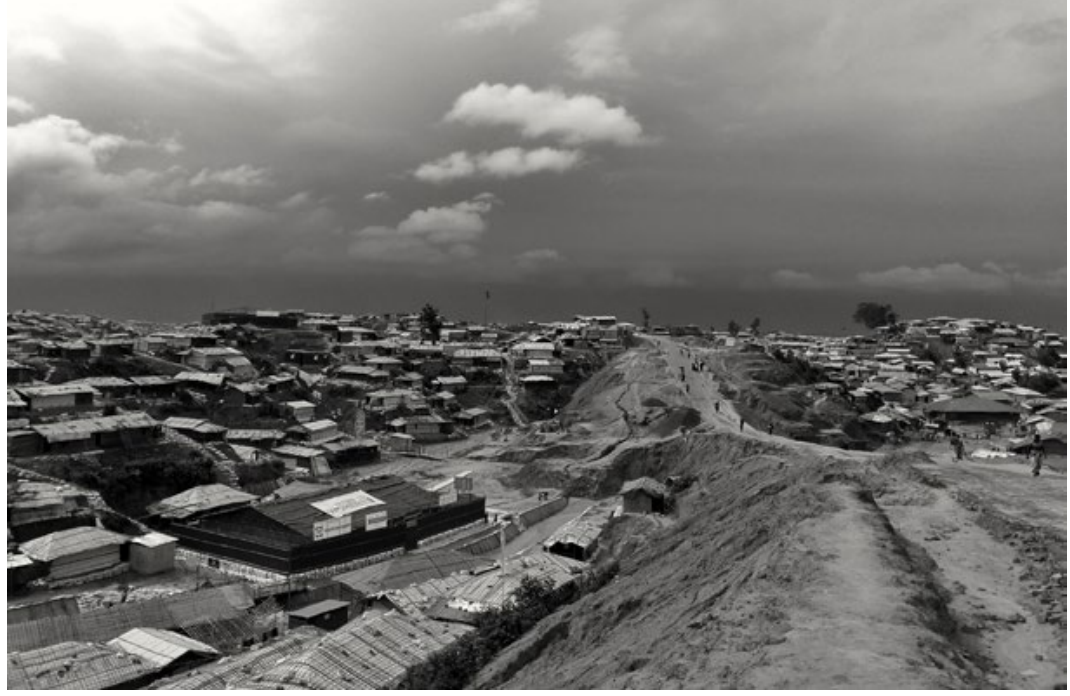

The Rohingya Refugee Camp, Bangladesh

Source: @Arnab Dasgupta, Flickr

as a refugee-generating country, and has generally maintained a low profile in the international discourse on refugee protection. Although remaining a major source of refugees and asylum seekers, China is also emerging as a destination and transit country and has demonstrated interest in greater involvement in refugee affairs. ${ }^{1}$ Leading scholars in refugee studies have noted that China is one of the most potentially influential actors in the international refugee protection regime. ${ }^{2}$

Having pledged to provide additional funds to aid international refugee assistance efforts at the $2016 \mathrm{UN}$ Summit for Refugees and Migrants and the 2017 Belt and Road Forum for International Cooperation, in 2018, China funded an unprecedented number of refugee aid projects in Asia and Africa, and gave much publicity to its refugee aid as well. This included: ${ }^{3}$
(1) US\$1 million aid to Syrian refugee students in Lebanon, through the United Nations International Children's Emergency Fund ${ }^{4}$

(2) US\$2 million for a program that upgraded essential services at Syrian refugee camps in the Kurdistan region of Iraq, through the $\mathrm{UNHCR}^{5}$

(3) US\$2 million for the provision of food and other materials to refugee camps in Zimbabwe, through the $\mathrm{UNHCR}^{6}$

(4) Funding for the rehabilitation of a community centre for Palestinian refugees in Baghdad, through the $\mathrm{UNHCR}^{7}$

(5) US\$6 million to aid refugees and drought-affected people in Ethiopia, through the World Food Program (WFP) $)^{8}$

(6) US\$1 million to Syrian and Iraqi refugees in Iran, through the WFP ${ }^{9}$ 
(7) US\$1.5 million to Syrian refugees in Jordan, through the WFP ${ }^{10}$

(8) US $\$ 500,000$ to Syrian refugees in Lebanon, through the WFP ${ }^{11}$

(9) About US\$500,000 for the safeguard of food security at refugee camps in Zimbabwe, through the WFP $^{12}$

(10) Offering to provide further humanitarian assistance, including emergency material aid and construction of facilities, to Rohingya refugees in Bangladesh. ${ }^{13}$

The fact that China made public pledges to fund refugee assistance projects and formed partnership with various international organisations to channel Chinese aid suggests a desire to be seen by the international community as an active contributor to the international refugee protection regime. This represents a shift from its previous low-key approach. At the 2017 Belt and Road Forum for International Cooperation, ${ }^{14}$ President Xi promised to provide US\$1 billion to international organisations for refugee-related projects in Asia and Africa, so China's monetary aid to refugees is likely to grow in the coming years.

Besides humanitarian assistance, in 2018, China continued with its offer to mediate between Bangladesh and
Myanmar on Rohingya refugees. It had already proposed a three-phase solution to the Rohingya refugee crisis in September 2017. This is one of the few occasions where China has actively sought to play the role of mediator, as the principle of non-interference has long been a cornerstone of Chinese foreign policy.

As pointed out by international and Chinese commentators, ${ }^{15}$ several factors have probably contributed to China's deepening involvement in the international refugee protection system. First, China has an interest in the stability of countries along the Belt and Road, especially where there are growing Chinese investments, which includes Bangladesh. Second, China's increasing involvement is consistent with its perceived ambition to position itself as a provider of public services and solutions to global problems. ${ }^{16}$ Third, the international community, especially the UNHCR, the European Union, Germany, Malaysia, and Bangladesh, has actively sought to engage China in issues around refugee protection. ${ }^{17}$

China's treatment of refugees and asylum seekers within China is another story. As of October 2018, the Chinese government does not process 


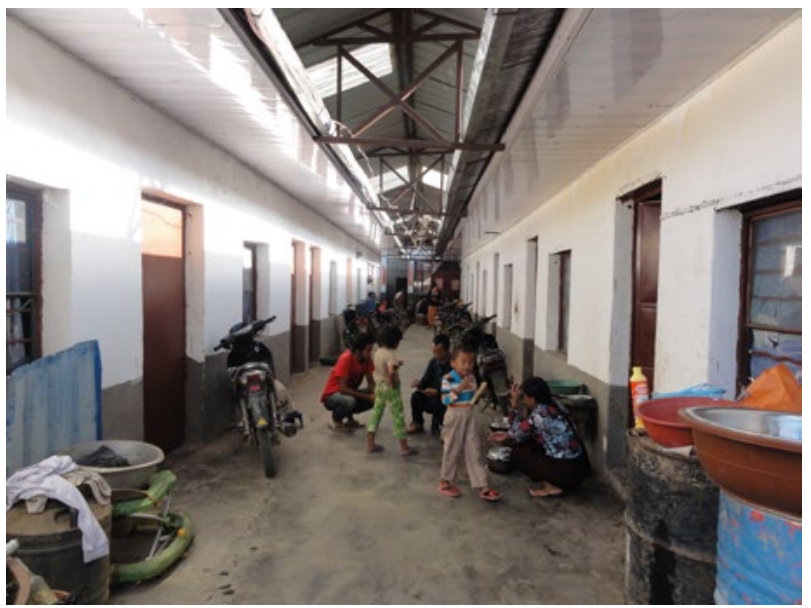

refugee claims, provides very limited financial support to refugees identified by the UNHCR, and does not allow them to work. ${ }^{18}$ Refugee advocates also criticise China's reluctance to grant the UNHCR access to North Korean escapees and displaced ethnic Kokangs and Kachins from Myanmar. If China aspires to establish itself as a solution provider in global refugee affairs, it will have to convince the international community that it upholds the core principles of refugee protection, including the principle of non-refoulement.

China may not be purely altruistic in its funding for international refugee protection. Yet its external refugee policies are set to make a major contribution to refugee welfare. Through constructive dialogue and strategic partnerships, the international community may be able to engage China even more deeply in the future in this matter of great global concern. 
This text is taken from China Story Yearbook 2018: Power, edited by Jane Golley, Linda Jaivin, Paul J. Farrelly and Sharon Strange, published 2019 by ANU Press, The Australian National University, Canberra, Australia.

doi.org/10.22459/CSY.2019.10A 